\title{
GCU
}

Glasgow Caledonian

University

University for the Common Good

\section{Assessment of net energy contribution to buildings by rooftop photovoltaic systems in hot-humid climates}

Dehwah, Ammar H.A.; Asif, Muhammad

Published in:

Renewable Energy

DOI:

10.1016/j.renene.2018.08.031

Publication date:

2019

Document Version

Author accepted manuscript

Link to publication in ResearchOnline

Citation for published version (Harvard):

Dehwah, AHA \& Asif, M 2019, 'Assessment of net energy contribution to buildings by rooftop photovoltaic systems in hot-humid climates', Renewable Energy, vol. 131, pp. 1288-1299.

https://doi.org/10.1016/j.renene.2018.08.031

\section{General rights}

Copyright and moral rights for the publications made accessible in the public portal are retained by the authors and/or other copyright owners and it is a condition of accessing publications that users recognise and abide by the legal requirements associated with these rights.

Take down policy

If you believe that this document breaches copyright please view our takedown policy at https://edshare.gcu.ac.uk/id/eprint/5179 for details of how to contact us. 


\title{
Humid Climates
}

\author{
Ammar H.A. Dehwah ${ }^{1,2}$ and Muhammad Asif ${ }^{1, *}$ \\ ${ }^{1}$ Architectural Engineering Department, King Fahd University of Petroleum \& Minerals, Dhahran 31261, \\ Saudi Arabia \\ ${ }^{2}$ Building Systems Engineering Program, Civil, Environmental and Architectural Engineering \\ Department, Boulder, CO 80309, USA; ammar.dehwah@ colorado.edu \\ *Correspondence: asifm@kfupm.edu.sa; Tel.: +966-13-860-7906
}

\section{Abstract}

The study aims to investigate the overall impact of rooftop photovoltaic (PV) systems on the energy performance of residential buildings in hot-humid climates. The study area spans over $100 \mathrm{~km}^{2}$ encompassing 33,000 residential units in the city of Al-Khobar in Saudi Arabia. It examines the restrictions towards the utilizability of building rooftops for PV application. The total building rooftop area and its corresponding PV output at the urban scale level has been estimated with the help of geographic information systems and PV simulation tools. The secondary contribution by PV in terms of heat gain reduction has also been investigated through EnergyPlus simulation engine. It is found that villas and apartment buildings respectively offer $21 \%$ and $28 \%$ of their rooftops for PV application. Results suggest that solar PV can offset $19 \%$ of the electricity demand when $25 \%$ of the building roof is utilized, in addition to a cooling load reduction of $2 \%$ due to the shading effect of panels. For the total study area, the annual electricity generation potential for tilted and flat application of PV with the existing roofs conditions turns out to be $797 \mathrm{GWh}$ and $757 \mathrm{GWh}$ respectively.

Key words: Solar energy; buildings; PV; urban scale; rooftop; Saudi Arabia

\section{INTRODUCTION}

Energy sustainability is one of the most critical areas of interest for countries across the world. In recent decades the Kingdom of Saudi Arabia (KSA) has witnessed a rapid growth in energy demand as a result of factors like population growth, urbanization and modernization (Mahalik et al., 2017). The country annually requires around $4 \mathrm{GW}$ of capacity addition in the power sector to meet the growing demand estimated at nearly $9 \%$ (Export.gov, 2017). Buildings hold the greatest share in the national power consumption with the residential sector alone accounting for 52\% of the total generation (Khan and Asif, 2017; Mahmoud et al., 2017). The country has historically relied on fossil fuels to meet all its energy needs. The situation is resulting into massive energy, environmental and economic stresses for the country (Alkhathlan and Javid, 
2015; Ouda et al., 2016). The annual per capita $\mathrm{CO}_{2}$ emissions are reported to be 15 metric tons ranking the country among the list of top 10 polluting nations (Dong et al., 2018; Olivier et al., 2016).

Responding to the escalating energy and environmental challenges and following the global trends, KSA has planned to diversify its energy supply base. Plans are in place to induct renewable energy in the supply mix to reduce reliance on oil and gas (Zell et al., 2015). The country has targeted to have 9,500MW of renewable energy projects by 2030 (Hutchins, 2017). Solar energy is the most important renewable resource available to the country (Baras et al., 2012; Mondal et al., 2016). Solar PV is the main renewable technology being focused on. With over 1,300MW of solar PV projects been planned to be developed by 2018, the emphasis has been on large and utility scale capacity addition. The worldwide progress of solar PV has been significantly helped by small scale and building related applications through conducive policies like net metering and feed-in-tariff (Asif, 2016). KSA does not have an active subsidy or financial incentives in place to support small scale application of PV. In 2017 the Electricity and Cogeneration Regulatory

Assessment of the potential of solar energy through installing rooftop PV systems has been an area of interest for research scholars across the world (Gautam et al., 2015; Hong et al., 2014; Karteris et al., 2013; Khan and Arsalan, 2016). The overall contribution by the application of PV at the city level has also been studied by researchers (Asif, 2016; Khan et al., 2017). Khan et al. (2017) have studied the power generation potential for PV application on residential buildings in KSA making wide ranging assumptions about roof utilizability. Asif (2016) investigated the power output potential of PV system in different types of buildings on a smaller scale again making assumptions about roof utilization. None of these two studies incorporated detailed modeling for example of a case study building. Dehwah et al. (2018) performed a detailed investigation for the potential of rooftop PV applications focusing mainly on the area utilization. None of these studies looked into the energy saving role of PV systems. Another contribution of PV on the energy performance of buildings is in terms of its influence on cooling/heating load. The effect of building integrated PV (BIPV) on heat gain through envelope has been considered in several studies (Ban-Weiss et al., 2013; Peng and Yang, 2016; Radhi, 2010; Sun and Yang, 2010; Wang et al., 2006; Zhang et al., 2017).

62 The impact of rooftop application of PV in terms of cooling load reduction has also been studied in various 63 countries i.e. USA (Dominguez et al., 2011), Greece (Kapsalis et al., 2014) and China (Wang et al., 2017).

64 In KSA, the experience with research and development, and demonstration projects has also been mainly 65 
power plant installed at King Abdullah Petroleum Studies and Research Center (KAPSARC) in Riyadh

67 (Asif, 2016; Khan et al., 2017). Due attention has not been paid to small scale application of PV, and there

68 is a lack of scholarship on the subject not only in the KSA but the whole Gulf Cooperation Council (GCC)

69 region. The influence of PV on the cooling/heating loads of PV is also an area which has not been addressed.

70 The present work is the first comprehensive study in the GCC region which investigates the application of

71 solar PV in buildings in terms of net energy contribution. It has also adopted a diverse research approach

72 involving use of satellite imaging, validation of results through site surveys, regression analysis, and

73 modeling with type of software tools. This study aims to estimate the overall impact rooftop application of

74 solar PV can make in hot-humid climates. The key objectives of the study are to:

75 - Examine applicability of PV on residential building rooftops

76 - Calculate energy output from PV systems at urban scale

77 - Estimate the impact of PV on buildings' heating and cooling loads

78 The study has been undertaken for residential buildings in the city of Al-Khobar in Saudi Arabia.

79 Utilizability of building rooftops for PV application has been estimated examining wide ranging 80 restrictions. The total building rooftop area at the urban scale has been calculated with the help of

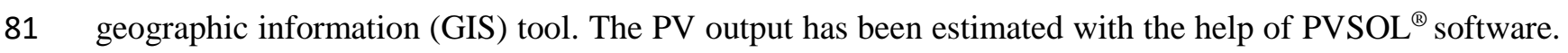

82 The secondary impact of PV in terms of energy saving as a result of reduction in cooling load due to shading

83 of roof has been modelled with the help of DesignBuilder software. An economic assessment has been 84 conducted to evaluate the feasibility of the PV system from a user perspective.

\section{RESEARCH APPROACH}

86 The study devised a four-stage research approach to determine the prospects of PV application in residential 87 buildings in Saudi Arabia. The four main building blocks of the research are: rooftop area assessment, PV 88 electricity production, reduction in electricity consumption and the total PV contribution at city scale as 89 depicted in Figure 1. 


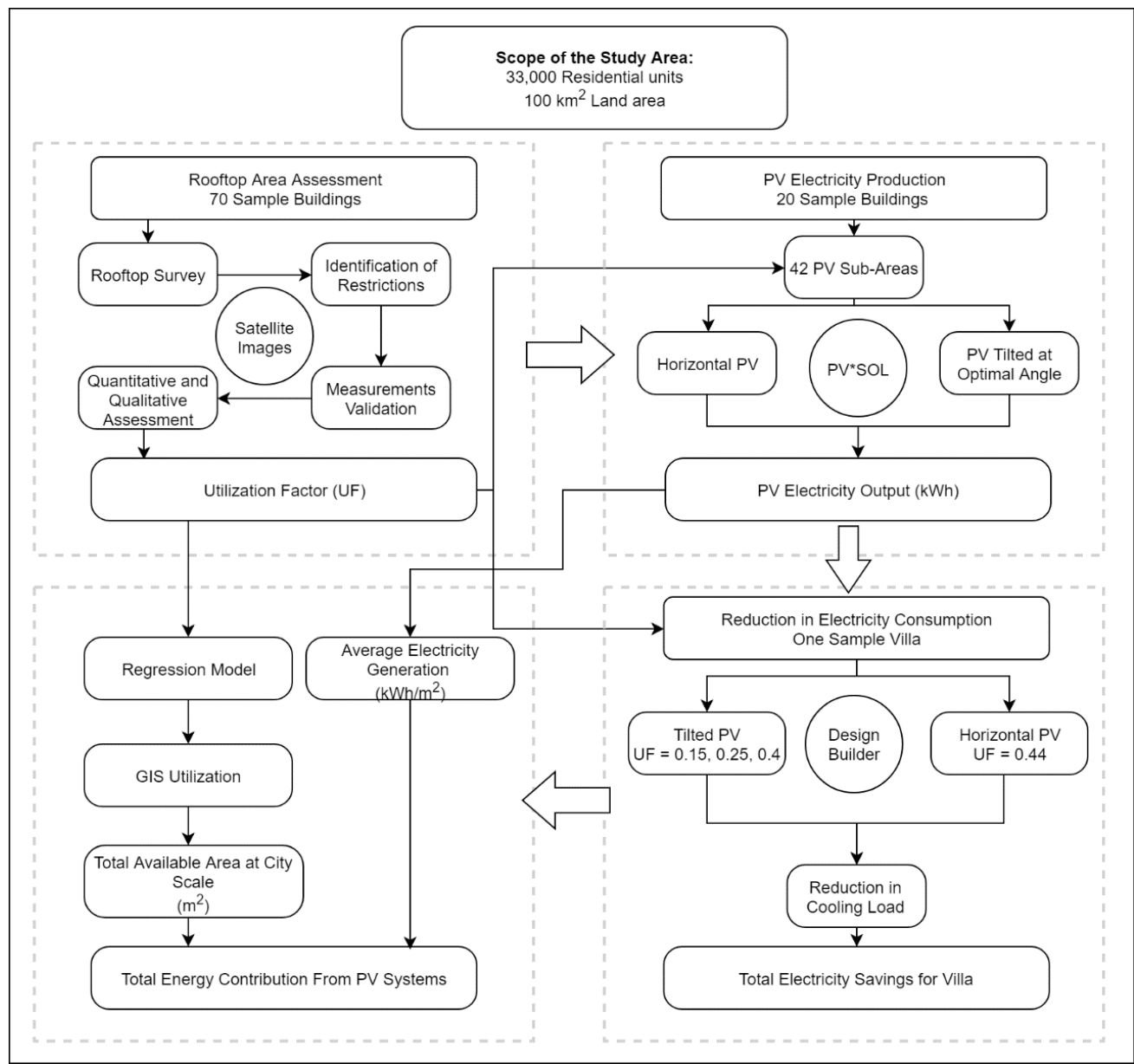

92 The first stage assesses the utilizability of building rooftops in Al-Khobar covering an area of $100 \mathrm{sq} \mathrm{km}$ encompassing 33,000 residential units including villas and apartments. The assessment has been carried out adopting a meticulous approach based upon advanced computational and modelling techniques coupled with detailed building surveys to systematically examine the nature of the residential building rooftops and features affecting the application of solar PV. A total of 70 sample buildings have been visited and audited to estimate the available roof area for PV installation.

98 In the second stage, the application potential for PV systems has been studied undertaking survey of 99 rooftops of 20 of these 70 buildings. Afterwards, taking into account the local weather conditions, detailed 100 design and optimization of PV systems has been carried out for an apartment and a villa unit as case studies. 101 Structural details of these case study buildings have also been provided. 
In the third stage, the impact of PV systems in terms of energy saving as a result of shading effect on roof has been studied. In this respect the case study villa unit has been modelled considering various scenarios of PV application on rooftops.

Finally, the results from the case studies have been extrapolated with the help of regression models to determine the PV potential at the city level.

\section{UTILIZABILITY OF BUILDING ROOFTOPS FOR PV APPLICATION}

Over the last couple of decades application of solar PV has found a great deal of success in the building sector across the world (Asif, 2016; Khan et al., 2017). Wide ranging regulations and policies have been developed to propel the use of PV in buildings. PV can be used in buildings on roof as well as on façade in various forms such as roof mounting, roof integration, façade integration and thin film coating on glass/windows. Majority of the PV applications in buildings are however on rooftops. Utilizability of building rooftops for PV application may vary significantly from place to place due to wide ranging architectural, structural and cultural features (Khan and Arsalan, 2016; Ko et al., 2015; Kurdgelashvili et al., 2016; Miranda et al., 2015; Wong et al., 2016). It is therefore important to duly investigate the building rooftop conditions to accurately estimate the potential for PV application at any particular place.

Investigation of building rooftops for PV use has been an area yet to be explored not only in KSA but also in the whole GCC region. This study employed the manual selection method to investigate the area available for PV application and then utilized GIS software and high resolution satellite images to extrapolate the analysis at the city scale covering an area of $100 \mathrm{sq} \mathrm{km}$ and 33,000 residential units. Furthermore, site visits were conducted to develop better understanding and gather data for 70 sample buildings in terms of their roof conditions and surroundings. Samples were selected from different residential neighborhoods in the city to account for the variation in building characteristics. Field measurements were also used to validate the area measurements taken from the satellite images. For the selected sample buildings, rooftops were visited to have a closer look at the roof features and to take relevant measurements for validation. Roof geometry conditions were obtained to validate the measurements taken from the high resolution satellite images. All rooftop components were surveyed in terms of quantities, dimensions and positioning on roof. It was noticed that majority of rooftops are flat and have a rectangular shape. The main restrictions (hurdles) for installing PV were identified and classified into five main categories - structural restrictions, services restrictions, accessibility, maintenance and inter-row spacing restrictions, shading restrictions and other restrictions - as summarized in Table 1. 
A utilization factor (UF), defined as the ratio of the available area for PV utilization to the total roof area, was calculated and used as an indicator for PV space availability. The main structural hurdles were observed to be: annexes, parapet walls, staircase rooms and roof geometry. Service hurdles were found to be: dish antennas, water tanks, air conditioning (AC) package units and condensers, and water boilers. Maintenance and accessibility hurdles involved areas nearby doors and ladders, areas for service maintenance and interrow spacing between PV panels. Rooftops were found to be used by occupants for various purposes such as open air sitting space and washing and drying space. These five categories of hurdles have a major impact on PV installation in terms of space utilization. However, structural and service components pose another significant impact in the form of electricity output reduction due to shading from the aforementioned elements' heights. It was noticed that dish antennas and water tanks exist on almost every roof with the former far outweighing other types of hurdles in terms of numbers.

Table 1: Classification of Main Restrictions

\begin{tabular}{|c|c|}
\hline Classification & Components \\
\hline Structural restrictions & $\begin{array}{ll}\text { - } & \text { Parapet walls } \\
\text { - } & \text { Annexes } \\
\text { - } & \text { Atrium shafts } \\
\text { - } & \text { Staircase, columns } \\
\text { - } & \text { Rebars } \\
\text { - } & \text { Roof geometry } \\
\end{array}$ \\
\hline Service restrictions & $\begin{array}{ll}\text { - } & \text { Water tanks } \\
\text { - } & \text { AC package units } \\
\text { - } & \text { Dish antennas } \\
\text { - } & \text { Atrium shaft area } \\
\text { - } & \text { AC condensers } \\
\text { - } & \text { Water boilers } \\
\end{array}$ \\
\hline Accessibility restrictions & $\begin{array}{ll}\text { - } & \text { Nearby access } \\
\text { - } & 1 \mathrm{~m} \text { adjacent to walls } \\
\text { - } & \text { Inter-row spacing } \\
\end{array}$ \\
\hline Shading restrictions & \begin{tabular}{|l} 
Impact of height from: \\
- Parapet walls \\
- Annexes \\
- Atrium shafts walls \\
- Staircase \\
\end{tabular} \\
\hline Other restrictions & $\begin{array}{ll}\text { - } & \text { Courtyard } \\
\text { - } & \text { Clothesline } \\
\end{array}$ \\
\hline
\end{tabular}

145 In order to calculate the UF for each building, the five categories of hurdles were quantified and represented 146 by coefficients: structural coefficient (Cstr), service coefficient (Cser), maintenance and accessibility 
coefficient (Cacc), shading coefficient (Csh) and finally a coefficient for other types of rooftop usage (Coth). The average values of the five rooftop restriction coefficients represented by Cstr, Cser, Cacc, Csh and Coth were calculated for apartment buildings as $0.85,0.57,0.67,0.90$ and 0.75 and for villas as 0.91 , $0.59,0.47,0.91$ and 0.93 respectively. The UF for each sample building was calculated by multiplying the aforementioned coefficients. It was found that the net UF ranged from 0 to 0.40 for apartment buildings with an average value of 0.21 . The net UF for villas was found to range from 0.15 to 0.44 with an average value of 0.28 . Figure 2 shows the frequency distribution of the UFs for the 70 building samples. Linear regression models were developed to find a correlation between PV utilizable area (UA) and roof area (RA) of the investigated buildings. The models are then used to extrapolate the results to the city level with the help of GIS software. The total available PV area (PVA) at city scale for apartment buildings and villas were calculated to be $1,460,340 \mathrm{~m}^{2}$ and $2,323,072 \mathrm{~m}^{2}$ respectively.

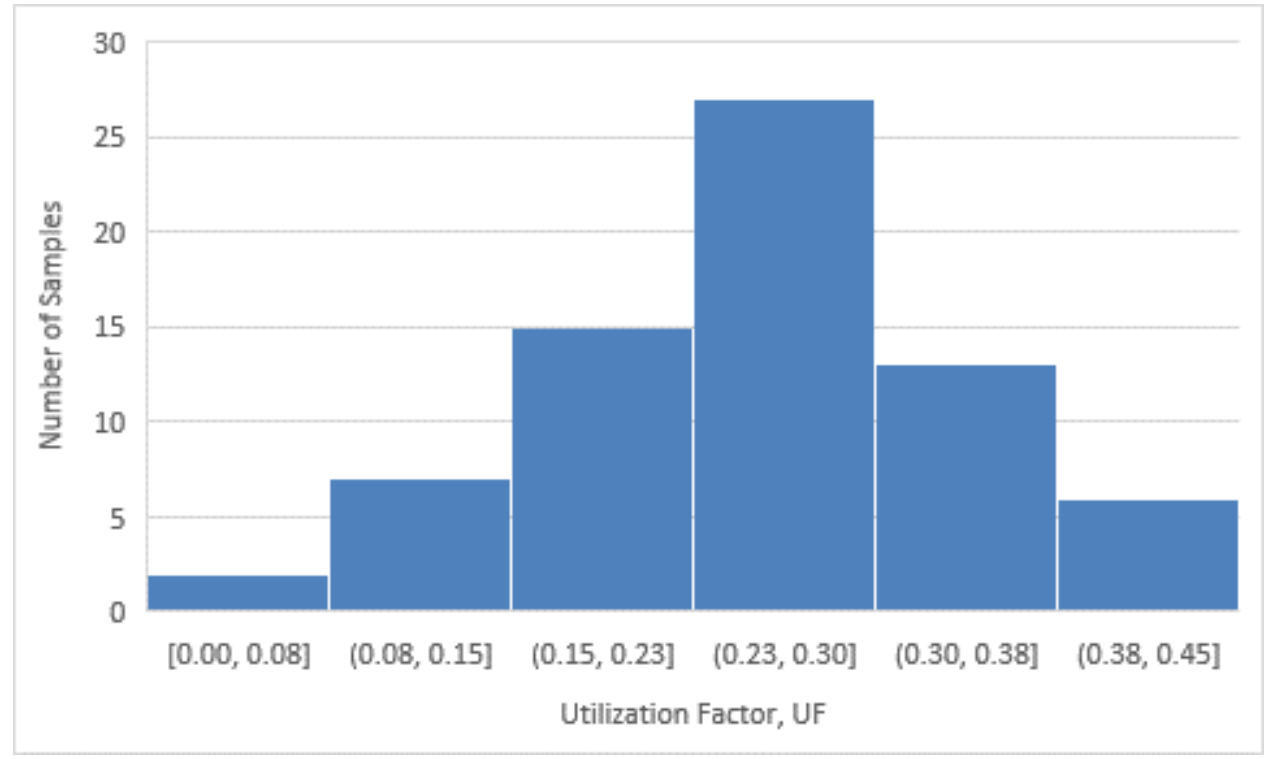

Figure 2: Frequency Distribution of UFs for the 70 Investigated Samples

\section{PV SYSTEM DESIGN}

\subsection{Weather Data}

The city of Al-Khobar is in close proximity of the city of Al-Dhahran that has the regional meteorological station. Since the two cities have identical climate condition, the weather data of Al-Dhahran has been used in the study. The two cities have desert climate with hot-humid summers and mildly cool winters. Figure 3 (a) depicts the average temperature conditions collected over a 38-year period. The hottest month is July with an average high temperature of $43^{\circ} \mathrm{C}$, though it can reach as much as $49^{\circ} \mathrm{C}$. The coldest month is January with an average low temperature of $11^{\circ} \mathrm{C}$. Summers in Al-Dhahran are considered very humid, as the average daily high relative humidity $(\mathrm{RH})$ ranges between $61 \%$ and $90 \%$, while the average daily low 
RH ranges between $15 \%$ and $46 \%$ throughout the year as can be seen from Figure 3 (b). The region has clear sky throughout the year with occasional dust storms that affect the PV output (Baras et al., 2017). PV with $24^{\circ}$ of tilt angle receives a daily irradiation of $6540 \mathrm{Wh} / \mathrm{m}^{2} /$ day with the monthly solar irradiation data 178 provided in Table 2 (Joint Research Centre (JRC), 2012).
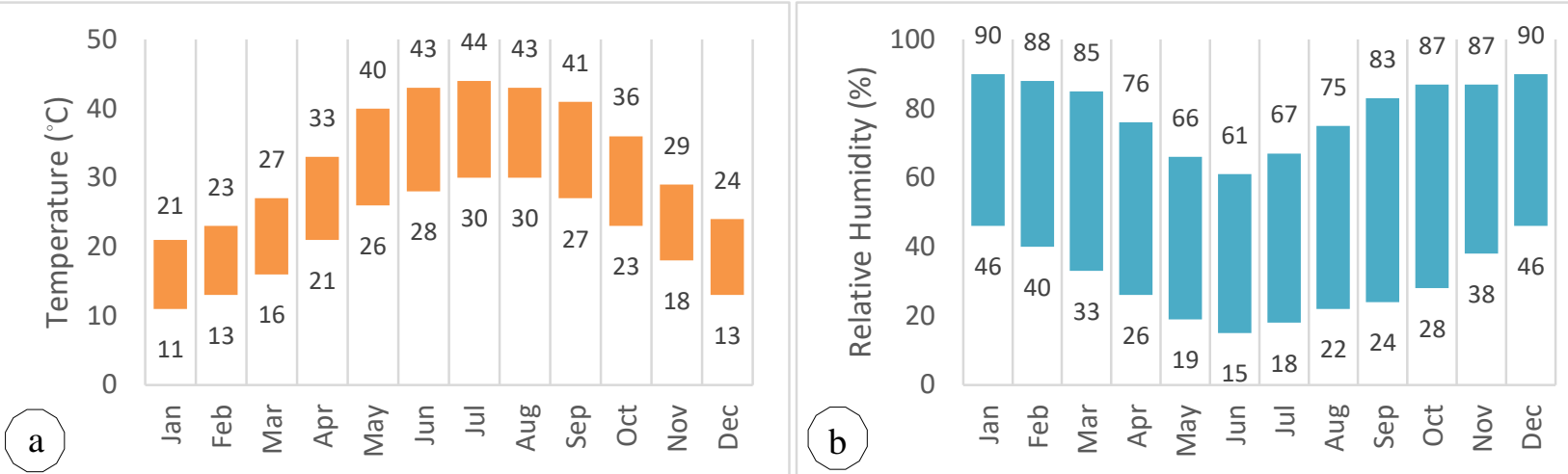

Figure 3: Average High and Low Weather Conditions in Al-Dhahran; a) Temperature and b) Relative Humidity

Table 2: Monthly Global and Direct Normal Irradiation Data for Al-Dhahran, Saudi Arabia (JRC)

\begin{tabular}{|c|c|c|c|c|}
\hline Month & $\mathrm{H}_{\mathrm{h}}$ & $\mathrm{H}_{\mathrm{opt}}$ & DNI & $\mathrm{I}_{\text {opt }}$ \\
\hline Jan & 3880 & 5080 & 4330 & 51 \\
\hline Feb & 4800 & 5820 & 4770 & 43 \\
\hline Mar & 6060 & 6720 & 5520 & 30 \\
\hline Apr & 6600 & 6680 & 5520 & 14 \\
\hline May & 7790 & 7340 & 6720 & 1 \\
\hline Jun & 8320 & 7530 & 7690 & -6 \\
\hline Jul & 7860 & 7270 & 6770 & -3 \\
\hline Aug & 7450 & 7320 & 6610 & 9 \\
\hline Sep & 6910 & 7450 & 6880 & 25 \\
\hline Oct & 5750 & 6870 & 6330 & 40 \\
\hline Nov & 4160 & 5310 & 4390 & 49 \\
\hline Dec & 3720 & 5020 & 4390 & 24 \\
\hline Year & 6110 & 6540 & 5830 & \\
\hline
\end{tabular}

Where:

$\mathrm{H}_{\mathrm{h}}$ : Irradiation on horizontal plane $\left(\mathrm{Wh} / \mathrm{m}^{2} /\right.$ day $)$

$\mathrm{H}_{\text {opt: }}$ Irradiation on optimally inclined plane (Wh/ $\mathrm{m}^{2} /$ day)

DNI: Direct normal irradiation ( $\mathrm{Wh} / \mathrm{m}^{2} /$ day)

$\mathrm{I}_{\text {opt: }}$ Optimal inclination (deg.) 


\subsection{Structural Details of the Case Study Buildings}

Two of the sample buildings, an apartment and a villa, are examined in detail as a case study. The selected apartment building consists of three stories with 4 flats per floor in addition to 2 flats on the roof (annexes). The roof is rectangular in shape with a gross area of $254 \mathrm{~m}^{2}, 1.7 \mathrm{~m}$ high parapet wall and a PV utilization factor of 0.13 . The studied villa is a single-family residence constructed in 2005. It consists of two floors with a total area of $504 \mathrm{~m}^{2}$. The roof is rectangular in shape with a gross area of $240 \mathrm{~m}^{2}$, a $3 \mathrm{~m}$ high parapet wall and a PV utilization factor of 0.15 . The two buildings in terms of size, function and construction respectively represent typical apartments and villas in the neighborhood. However, in terms of roof features there is a great degree of variation from building to building and hence it is difficult to find a typical roof in terms of PV utilization. Table 3 summarizes the characteristics of the two buildings. Their rooftops are significantly occupied, posing various types of restriction for PV applications as shown in Figure 4.

Table 3: Key Characteristics of the Two Sample Building

\begin{tabular}{|l|c|c|}
\hline & Apartment building & Villa \\
\hline Floors & $3+$ Annex & - \\
\hline Number of flats & 14 & 240 \\
\hline Roof Area $\left(\mathrm{m}^{2}\right)$ & 254 & 1.7 and 3.0 \\
\hline Parapet wall height $(\mathrm{m})$ & 1.7 & 0.15 \\
\hline Utilization Factor, UF & 0.13 & 63,757 \\
\hline Annual Consumption $(\mathrm{kWh})$ & 188,740 & \\
\hline
\end{tabular}
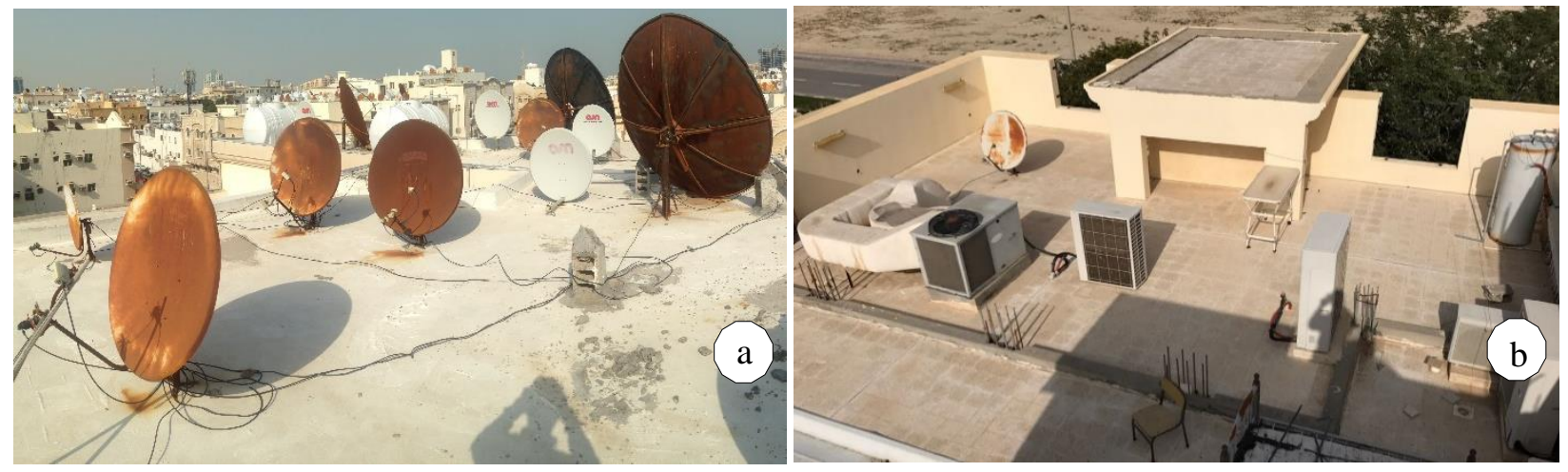

Figure 4: Roofotp Utilization of a Typical (a) Apartment Building and (b) Villa 
The villa sample has been used to examine the impact of PV on building energy consumption. To evaluate the energy savings due to the shading effect of PV, building's construction and system details were needed. Building drawings including structural, architectural and lighting details were collected from the owner. Other information needed for the simulation such as energy systems types and operational schedule of appliances, lighting and $\mathrm{AC}$ systems were obtained through inspecting the building and interviewing the building owner. Table 4 summarizes the relevant characteristics and specifications of the studied villa.

\section{Table 4: Base Case Module Characteristics}

\begin{tabular}{|l|l|}
\hline Building Characteristic & Description \\
\hline Location & Al-Khobar \\
\hline Orientation & Main elevation facing East \\
\hline Floor to Floor Height & $3.5 \mathrm{~m}$ \\
\hline Floor Area & Total: $504 \mathrm{~m}^{2}$; Ground Floor: $264 \mathrm{~m}^{2}$; First Floor: $240 \mathrm{~m}^{2}$ \\
\hline Window to Wall Ratio (WWR) & $8 \%$ \\
\hline \multirow{2}{*}{ Exterior Walls } & $\begin{array}{l}13 \mathrm{~mm} \text { Plaster / } 100 \mathrm{~mm} \text { Concrete Block (Medium) / 30mm } \\
\text { Extruded Polystyrene / 100mm Concrete Block (Medium) } \\
13 \mathrm{~mm} \text { Plaster } \\
\text { U-Value: } 0.58 \mathrm{~W} / \mathrm{m}^{2} \mathrm{k}\end{array}$ \\
\hline Roof & $\begin{array}{l}30 \mathrm{~mm} \text { Terrazzo Tiles / 30mm Extruded Polystyrene / 200mm } \\
\text { Reinforced Concrete / } 13 \mathrm{~mm} \text { Plaster } \\
\text { U-Value: } 0.97 \mathrm{~W} / \mathrm{m}^{2} \mathrm{k}\end{array}$ \\
\hline Windows & Single glazed with aluminum frame \\
\hline Lighting & Ground Floor: $20 \mathrm{~W} / \mathrm{m}^{2} ;$ First Floor: $12 \mathrm{~W} / \mathrm{m}^{2}$ \\
\hline AC & Split Units and One Central AC \\
\hline
\end{tabular}

The overall energy contribution from the application of PV in buildings consists of the power output plus the energy saving achieved as a result of cooling load reduction due to the shading effect of panels. Both the energy production and energy saving components have been determined with the help of PVSOL ${ }^{\circledR}$ and DesignBuilder software tools respectively. The approach adopted to determine the overall energy 


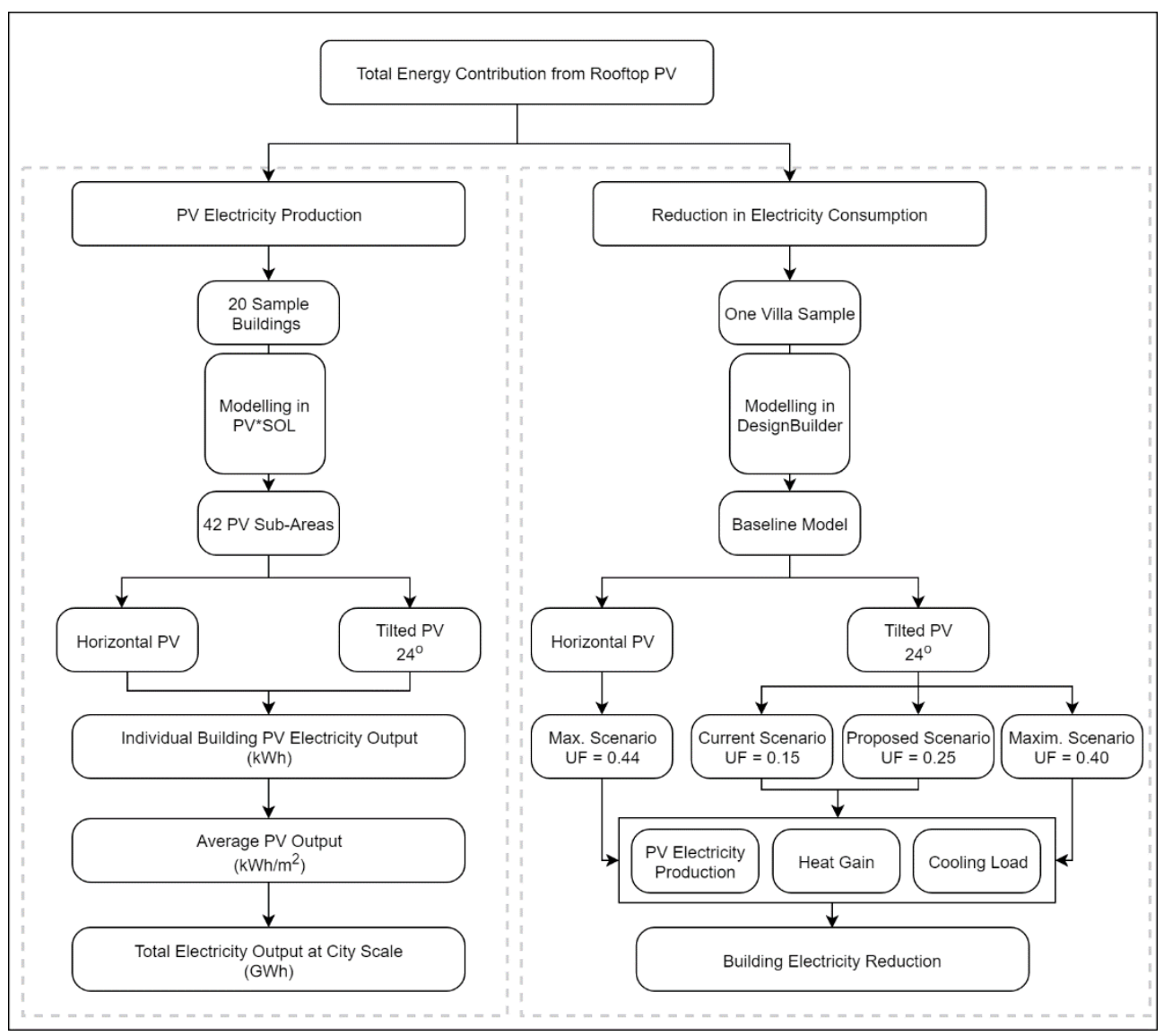

Figure 5: Total Energy Contribution From PV Systems

\subsection{PV System Modelling}

231 The PV system design and simulation exercise was carried out with the help of PVSOL ${ }^{\circledR}$ premium 2017 232 software for the 20 sample buildings. The $\mathrm{PVSOL}^{\circledR}$ software gives user the possibility to work on $2 \mathrm{D}$ or

233 3D models when designing PV system. When selecting 2D option, the software requires user input for array 234 and inverter details such as the number of modules, mounting conditions, tilt and orientation as well as 235 shading. On the other hand, 3D design option allows creating a 3D model of building geometry including 236 rooftop components as well as creating PV module formation.

237 A satellite image of the investigated villa was extracted and then imported to PVSOL ${ }^{\circledR}$. The image needed 238 to be calibrated to reduce errors from measurements. Geometry of the building roof was traced as a polygon 239 on the imported image to guarantee the exact orientation and then the polygon was extruded considering 240 the height of the building. An annex was also added as a building component to allow the software to treat 241 its roof as a normal roof and hence allowing components to be added. All existing rooftop components were 
modeled including parapet walls, dish antennas, AC condensers and water tanks. Noting that water tank does not exist in the predefined objects library, it was represented as a rectangular 3D object.

244 The next step involved selection of PV array system including PV module type, orientation and tilt angle.

245 The software then optimizes the inter-row distance or mounting support clearance as described in PVSOL ${ }^{\circledR}$. 246 PV module type was selected based on performance as well as area considerations. From the wide range of 247 PV modules available in market, the selected PV one was found to be suitable for residential applications. 248 The PV modules are of monocrystalline silicon type with $15.2 \%$ efficiency (BP Solar, n.d.), $190 \mathrm{~W}$ output 249 and a module area of $1.25 \mathrm{~m}^{2}$. This type was found suitable for residential application especially with the 250 small area available for installation. Technical specifications of the selected PV module are provided in 251 Table 5.

Table 5: PV Modules' Technical Details

\begin{tabular}{|l|l|}
\hline Parameter & Description \\
\hline Model & BP 4190T \\
\hline Cell type & Monocrystalline \\
\hline Output power at STC & $190 \mathrm{~W}$ \\
\hline Output power at NOCT & $137 \mathrm{~W}$ \\
\hline Efficiency & $15.2 \%$ \\
\hline Module area & $1.25 \mathrm{~m}^{2}$ \\
\hline
\end{tabular}

254 Two scenarios were examined in terms of PV installation; for south orientation inclination has been considered at optimal tilt angle of $24^{\circ}$ as well as horizontal with $0^{\circ}$ tilt angle. Figure 6 provides a detailed description of key parameters with regards to PV array dimensions. The inter-row spacing was optimized based on shading analysis on winter solstice, $21^{\text {st }}$ of December where the sun elevation angle is minimum and equal to $40.3^{\circ}$. The inter-row spacing or mount support clearance $\left(\mathrm{d}_{1}\right)$, which is the distance from the front edge of a module in one row to the front edge of a module in the next row, was optimized to be 0.40 m respectively. 


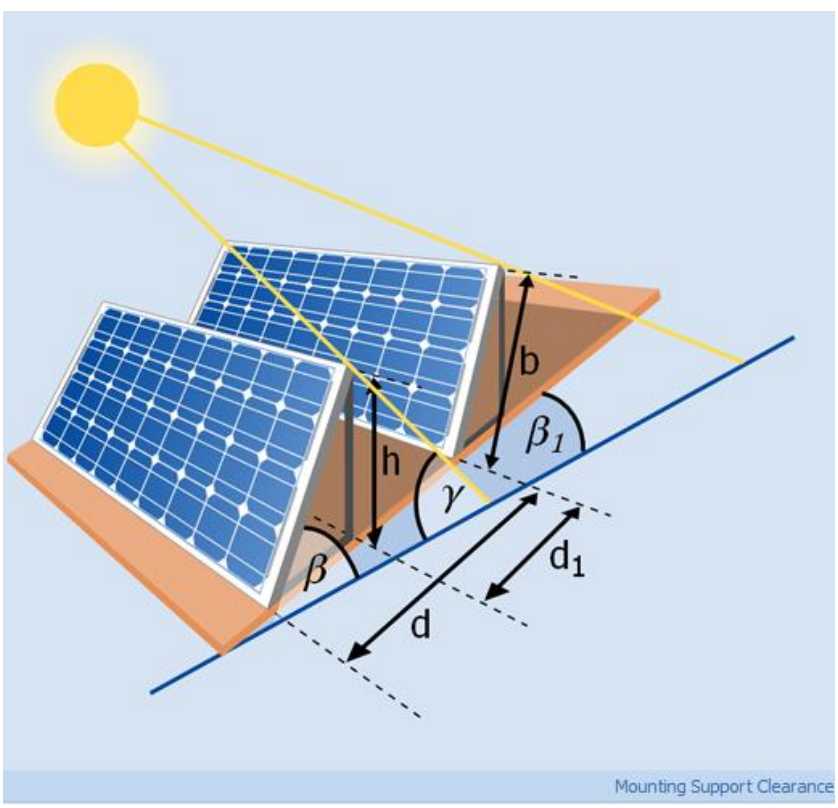

\begin{tabular}{|l|l|}
\hline Reference & Value \\
\hline Module mount width (b) & $0.79 \mathrm{~m}$ \\
\hline Mount height (h) & $0.32 \mathrm{~m}$ \\
\hline Module inclination (B) & $24^{\circ}$ \\
\hline Module orientation & $180^{\circ}$ \\
\hline Solar elevation angle & $40.29^{\circ}$ \\
\hline Solar elevation angle time & $21 / 12-$ \\
$12: 00$ \\
\hline $\begin{array}{l}\text { Depth of row (d-d }) \\
\text { Mounting support clearance } \\
\text { (d } 1 \text { ) }\end{array}$ & $0.72 \mathrm{~m}$ \\
\hline Row spacing $(\mathrm{d})$ & $0.40 \mathrm{~m}$ \\
\hline
\end{tabular}

Figure 6: Design Parameters for the PV system

274 Figure 7 shows the developed 3D model with rooftop components and the installed PV array. It can be noticed that PV panels are installed only on the right side of the roof which is the only available area. The area at the upper-left corner is being used as a courtyard. The remaining areas are occupied by service components i.e. dish antennas and water tanks. An edge distance of $1 \mathrm{~m}$ from all directions is excluded for accessibility and maintenance and to keep PV panels away from parapet walls to minimize shading impact.

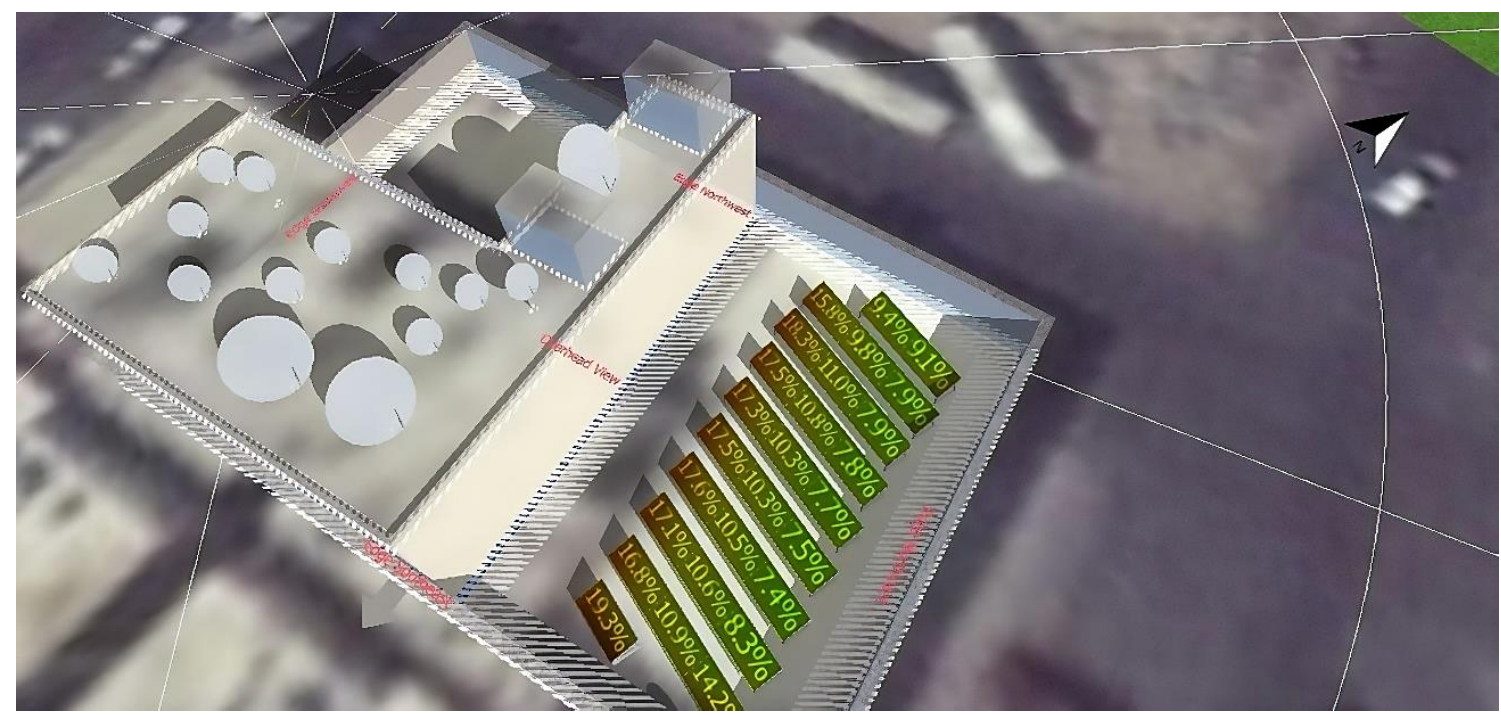

Figure 7: 3D Model with Shading Analysis for Apartment Building Using PVSOL ${ }^{\circledR}$ 
After modeling the PV array, shading frequency analysis was performed to determine the amount of annual direct irradiance reduction. The percentages shown in Figure 7 represent the annual average irradiance reduction at each panel due to shading. Modules with $20 \%$ or higher irradiance reduction, due to shading, were excluded as they could significantly reduce the output of the string, and also due to the economic considerations.

PV panels are configured by assigning inverters to the array system. PVSOL ${ }^{\circledR}$ offers the option of optimizing PV module configuration by selecting the arrangement that maximizes output. Shading has a major influence on the array characteristic and decisively affects the optimum configuration of the modules in strings. The optimized configuration divides modules into strings each with a color indicator. A system check can be done after the configuration which indicates any existing errors.

291 Given the objective to estimate the energy potential at city scale, it is required to extrapolate the results obtained from the unit scale energy production. PV sub-areas were introduced for each building based on the array condition. The 20 sample buildings included a total of $42 \mathrm{PV}$ sub-areas. Figure 8 shows a sample building with 4 PV sub-areas. Each PV sub-area represents a unique case in terms of geometry area and the amount of shading received. The simulation was conducted for all of the 20 sample buildings and then it was normalized to provide an indicator in terms of $\mathrm{kWh} / \mathrm{m}^{2} / \mathrm{yr}$.

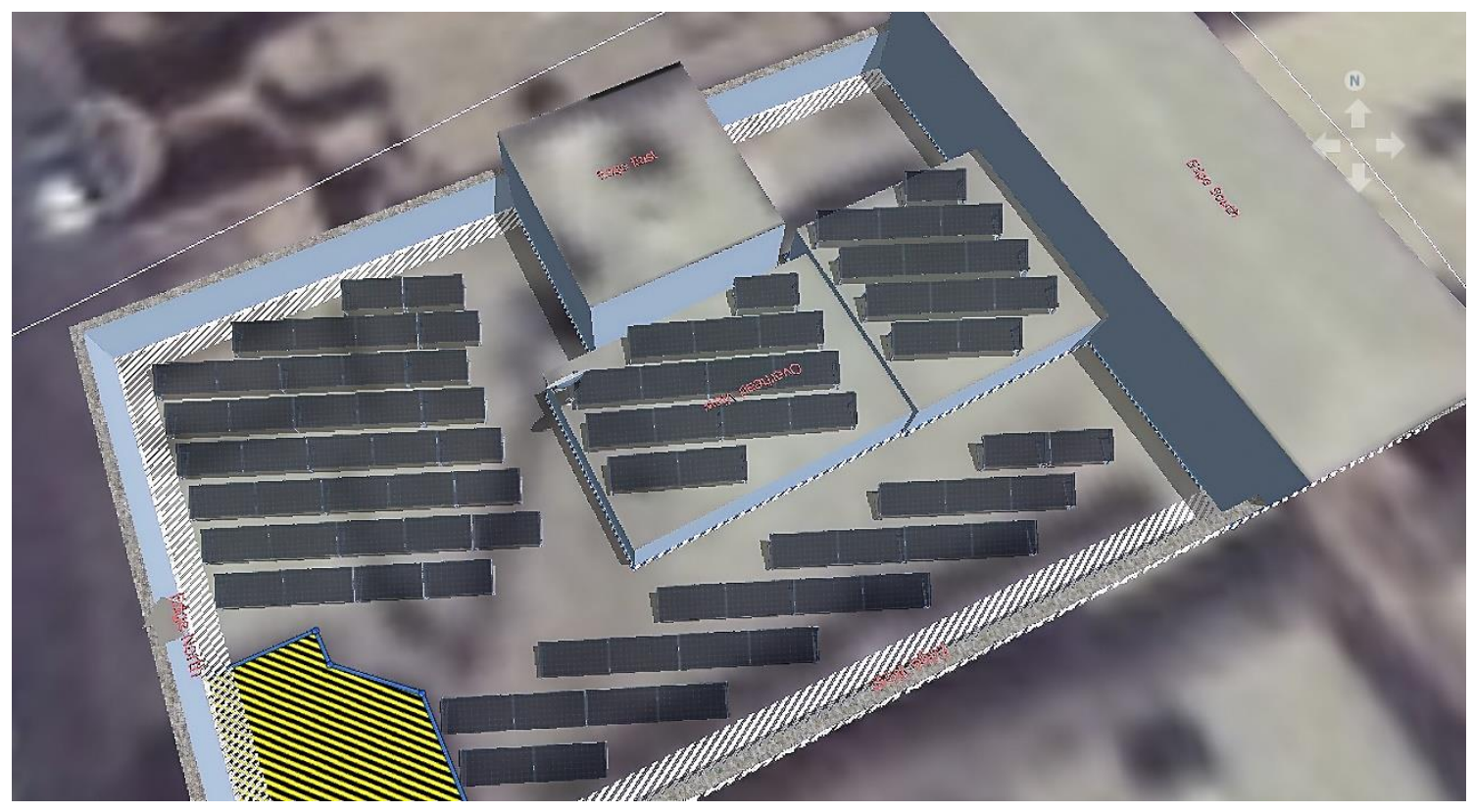


The impact of PV on building energy performance was investigated with the help of a BES tool. DesignBuilder software that employs EnergyPlus simulation engine was used in this study to determine the energy saving associated with PV system. Various scenarios were considered to cover a potential range of roof utilization factors. With existing roof arrangements, the modelled villa has a low-end UF of 0.15 . It has also been modeled assuming average and high-end UFs of respective values 0.25 and 0.4 . To undertake the overall energy output assessment, a base case building model needed to be developed in DesignBuilder.

The workflow of DesignBuilder software starts with selecting a weather file for the desired location. The software then allows the creation of building geometry, defining building type, activities and building characteristics. Despite the number of rooms in the villa, each floor was considered as one single zone for simplicity. All the details and specifications were fed into DesignBuilder to complete the model. Figure 9 shows a 3D view of the villa model developed in DesignBuilder. Before running the simulation it was necessary to input operational schedule for equipment, lighting and AC systems. The simulation was performed for an entire year on a monthly basis.

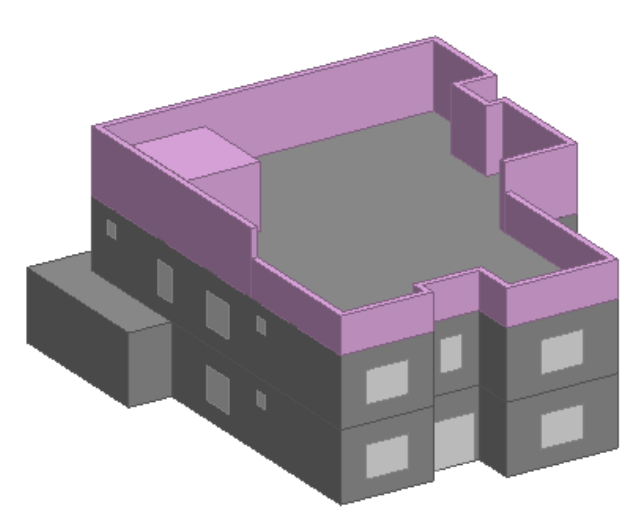

Figure 9: 3D View of the Villa Model

After the completion of the base case, PV modules were modelled on rooftop to determine the power output. DesignBuilder allows for the creation of PV panels and their integration within the building model. As the software is not designed initially to integrate PV technology, it can simulate a limited number of modules. Hence, each PV string was modeled representing a single PV unit having a multiplication of one module area. This allows the software to handle a large number of modules and simplifies the process. A grid connected system was considered with a base load operation scheme and direct current with inverter as the 
electrical buss type. The first scenario took into consideration the actual condition of the villa in terms of availability of space for PV applications. PV modules where integrated on the rooftop considering UF of 0.15. The second and third scenarios considered utilization factors of 0.25 and 0.40 respectively. The simulation was performed for the three cases to determine their respective contribution. Figure 10 shows a 3D-view of the three scenarios modelled in DesignBuilder.
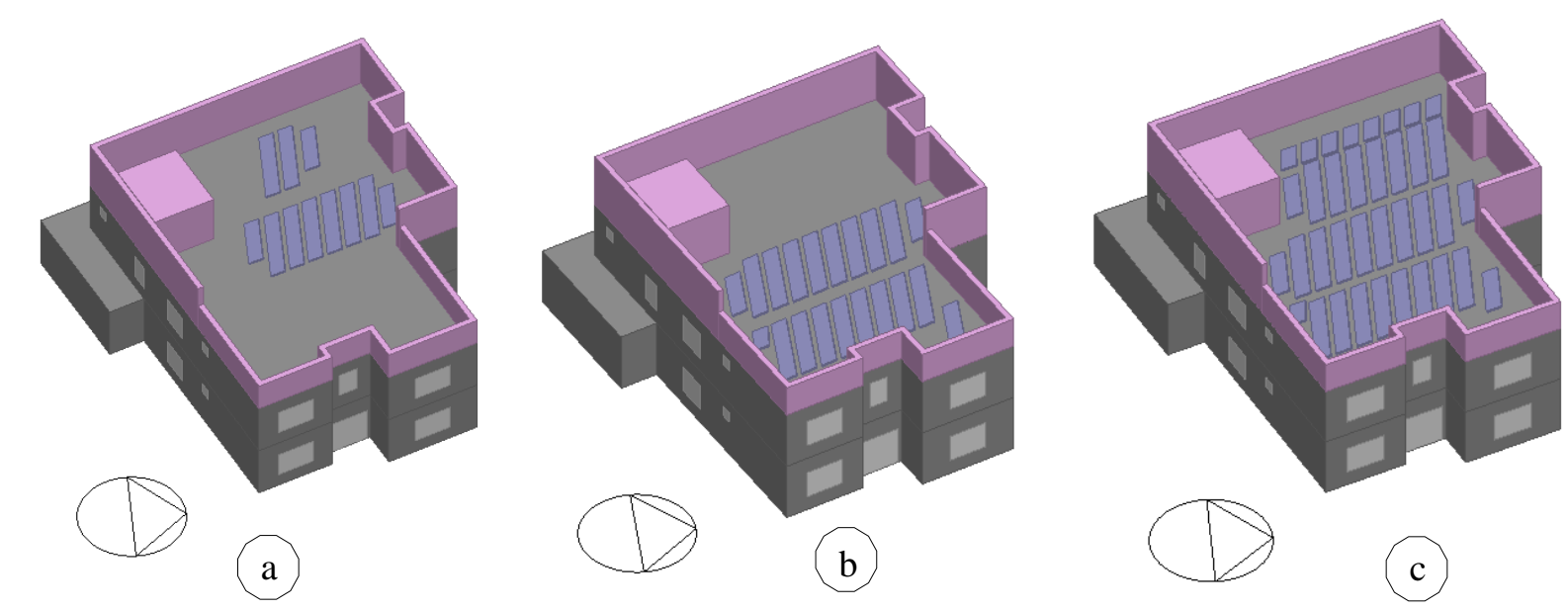

Figure 10: $3 D$ View of the Three Scenarios with UF: (a) 0.15 , (b) 0.25 and (c) 0.40

On top of producing electricity, rooftop PV systems also influence the energy performance of buildings through the shadow they cast on the roof structure. PV panels in this case act as an additional layer barring penetration of direct solar radiation onto roof surface. This indirect contribution of solar PV to buildings' energy performance has only been scarcely addressed in literature especially in the hot-humid Middle Eastern environment. Dominguez et al. (2011) investigated the impact of tilted and flat PV panels on roof heat transfer under California climate using the crank-Nicholson method. The study concluded that considerable benefits in terms of cooling load reduction can be obtained from PV application. Wang et al. (2006) compared three options of BIPV as part of the roof structure in terms of their impact on heating and cooling loads using one-dimensional transient model. The study, conducted under China's climate, concluded that rooftop BIPV with ventilated air gap is the optimum option for summer period. It also indicates that cooling load reduction can vary depending on several factors including local climate, existing insulation level and material absorptivity. The present study tries to investigate the additional impact of PV panels on the heat gain through the roof and eventually quantifying the cooling load reduction using EnergyPlus simulation environment. 
356 The economic viability of PV systems is an important factor for home owners to decide about the adoption of technology. The economics of PV systems may vary from case to case due to factors like local weather conditions, building conditions in terms of energy use and roof utilization. The levelized cost of electricity (LCOE) is one of the most commonly used indicator to determine the economic viability of electricity generation technologies (Al Garni et al., 2018; Lai and Mcculloch, 2017; Sadati et al., 2018). LCOE can be calculated using equation (1):

$$
L C O E=\frac{C_{A}+C_{(O \& M) A}}{E_{A}}
$$

362

363

364

365

Where $\mathrm{C}_{\mathrm{A}}$ is the initial cost (annual), $\mathrm{C}_{(\mathrm{O} \& \mathrm{M}) \mathrm{A}}$ is annual operating and maintenance $(\mathrm{O} \& \mathrm{M})$ cost and $\mathrm{E}_{\mathrm{A}}$ is annual electricity production. In the present study, the initial cost that takes into consideration the overall PV system is determined based upon the feedback gathered from local market to be $\$ 1330 / \mathrm{kW}$. The overall operation and maintenance (O\&M) cost is considered to be $1 \%$ of the initial cost (Adaramola and Paul, 2017). The O\&M cost also includes replacements cost; mainly inverters are replaced every 10 years with 9\% of the initial cost (Zweibel, 2010). The life expectancy for PV panels and inverters is 25-30 years and 10 years respectively. Interest rate is considered to be $2 \%$ based on the average of the previous 10 years (Trading Economics, 2018). The villa sample with UF of 0.15 has been selected as a representative building for the LCOE analysis. The LCOE analysis considers the slab based electricity tariff structure in KSA. The slab based tariff structure includes Saudi Arabian Riyal (SAR) 0.18/kWh (equivalent to $\$ 0.048 / \mathrm{kWh}$ ) for monthly consumption of up to $6000 \mathrm{kWh}$ and SAR $0.30 / \mathrm{kWh}(\$ 0.08 / \mathrm{kWh})$ for over $6000 \mathrm{kWh}$ of consumption.

\section{RESULTS AND DISCUSSION}

This section discusses the results of the energy production and savings from the installed rooftop PV system at unit scale. It also discusses the results extrapolated at city level and economics of PV system

\subsection{Energy Production at Unit Scale}

Electricity production from PV systems for the 20 sample buildings was simulated using PVSOL ${ }^{\circledR}$ software considering $24^{\circ}$ and $0^{\circ}$ tilt angles. Table 6 shows the simulation results for the two sample buildings: an apartment and a villa. The annual electricity generation from the $5.1 \mathrm{kWp}$ tilted PV system installed on the apartment building was found to be $6,079 \mathrm{kWh}$ considering an annual irradiance reduction of $20.1 \%$ due to shading. For flat application, the installable PV capacity increased to $6.8 \mathrm{kWp}$, generating 7,380 kWh/yr with an annual irradiance reduction of $21.4 \%$ due to shading. A flat PV array does not require spacing between module rows as is the case with tilted systems, resulting into greater installed capacity. The specific 
annual yield was found to be $1,185 \mathrm{kWh} / \mathrm{kWp}$ and $1,079 \mathrm{kWh} / \mathrm{kWp}$ for titled and flat installation respectively. Both scenarios showed a performance ratio of about $60 \%$. Based on the area covered by modules $\left(34 \mathrm{~m}^{2}\right.$ and $45 \mathrm{~m}^{2}$ ), the PV output generation per unit area turns out to be $179.8 \mathrm{kWh} / \mathrm{m}^{2} / \mathrm{yr}$ and $163.6 \mathrm{kWh} / \mathrm{m}^{2} / \mathrm{yr}$ for tilted and flat systems respectively. The PV system installed on the villa's rooftop shows similar characteristics as summarized in Table 6.

Table 6: Results of PV Application in the Case Study Apartment and Villa Buildings

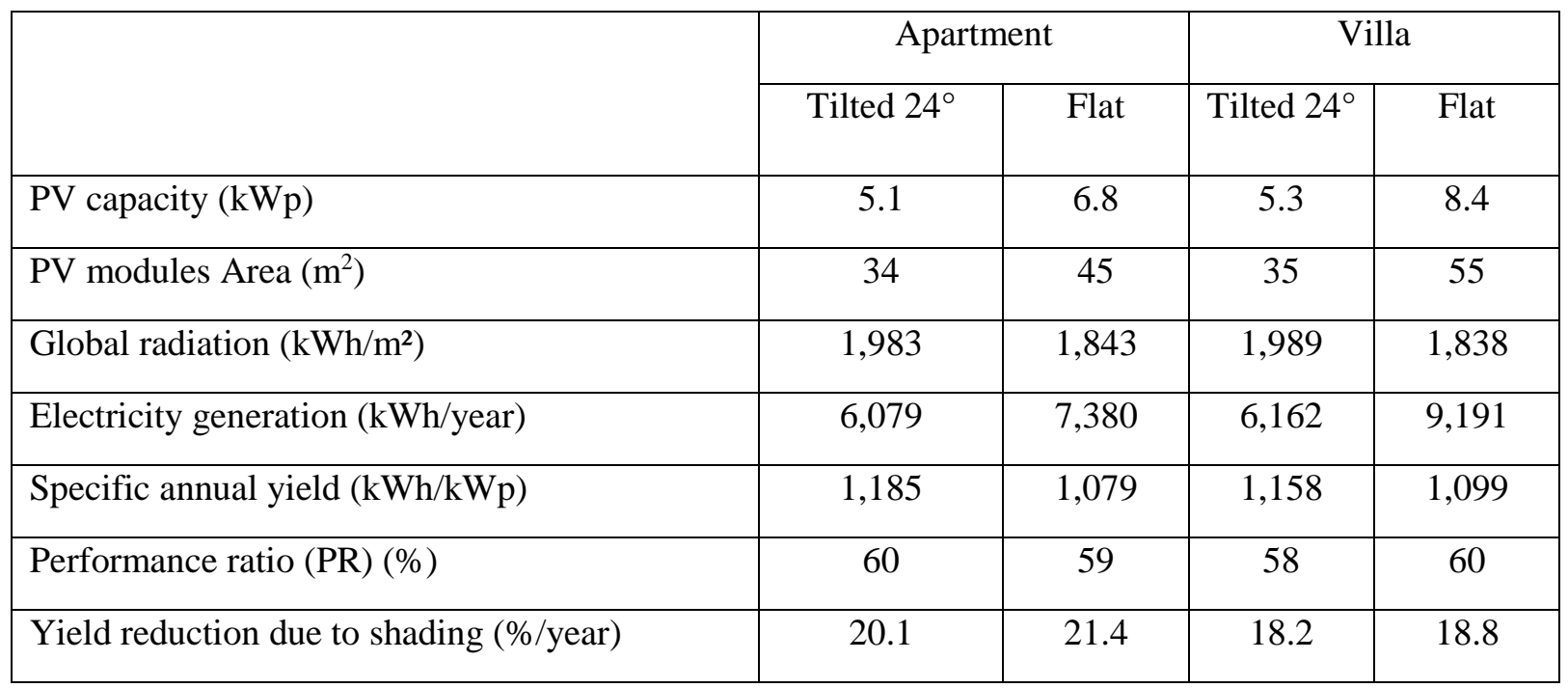

Table 6 shows sample results for selected villa and apartment building while Table 7 shows the results of all 20 sample buildings encompassing $42 \mathrm{PV}$-sub areas. The minimum, average and maximum values of several energy parameters for all $42 \mathrm{PV}$ sub-areas (as described in section 5.1) are summarized in Table 7. The results indicate that the simulated PV systems have an average specific annual yield of $1,391 \mathrm{kWh} / \mathrm{kWp}$ and exhibit a performance ratio of $70 \%$. Shading impact turns out to be high with an annual average yield reduction of $13.4 \%$. For the $42 \mathrm{PV}$ sub-areas, the average electricity output per unit area is computed to be $210 \mathrm{kWh} / \mathrm{m}^{2} / \mathrm{yr}$ and $204 \mathrm{kWh} / \mathrm{m}^{2} / \mathrm{yr}$ for tilted and horizontal panels respectively as shown in Table 7. A breakdown of the average electricity production in terms of apartment and villas reveals respective values of $207 \mathrm{kWh} / \mathrm{m}^{2} / \mathrm{yr}$ and $213 \mathrm{kWh} / \mathrm{m}^{2} / \mathrm{yr}$ when considering tilted PV scenario, while it is found to be 203 $\mathrm{kWh} / \mathrm{m}^{2} / \mathrm{yr}$ and $207 \mathrm{kWh} / \mathrm{m}^{2} / \mathrm{yr}$ for flat PV application in the same order.

Table 7: Energy Parameters for 42 PV Sub-Areas of the 20 Sample Buildings

\begin{tabular}{|l|c|c|c|}
\hline \multicolumn{1}{|c|}{ Parameter } & Minimum & Average & Maximum \\
\hline Capacity (kWp) & 1.0 & 4.0 & 13.7 \\
\hline
\end{tabular}




\begin{tabular}{|l|c|c|c|}
\hline Specific annual yield $(\mathrm{kWh} / \mathrm{kWp})$ & 1,008 & 1,391 & 1,589 \\
\hline Performance ratio & 56 & 70 & 77 \\
\hline Yield reduction due to shading $(\%)$ & 3.1 & 13.4 & 31.8 \\
\hline PV energy/module area $\left(\mathrm{kWh} / \mathrm{m}^{2} / \mathrm{yr}\right)-$ Tilted $24^{\circ}$ & 152 & 210 & 238 \\
\hline PV energy/module area $\left(\mathrm{kWh} / \mathrm{m}^{2} / \mathrm{yr}\right)$ - Horizontal & 158 & 204 & 230 \\
\hline Total generated energy $(\mathrm{kWh} / \mathrm{yr})-$ Tilted 24 & \multicolumn{3}{|c|}{258,557} \\
\hline Total generated energy $(\mathrm{kWh} / \mathrm{yr})-$ Horizontal & \multicolumn{3}{|c|}{} \\
\hline
\end{tabular}

403

404

405

406

407

\subsection{Net Energy Contribution from PV Application}

The base case energy simulation of the villa (with $504 \mathrm{~m}^{2}$ of conditioned area) showed a total energy load of $63,756 \mathrm{kWh} / \mathrm{yr}$ composed of: $63 \%$ cooling, $24 \%$ lighting and $13 \%$ appliances. The results of the three scenarios mentioned in section 5.1 are discussed here. The electricity generation from tilted application of PV within the utilizable area (UA) can offset $10 \%$ of the building's annual energy requirement. It is important to note that the Saudi residential units have a much higher energy consumption by international standards (Alrashed and Asif, 2014). Increasing the utilizable area from 0.15 to 0.25 improves the PV electricity contribution from $10 \%$ to $19 \%$. Further increasing the utilizable area to $40 \%$ results into electricity contribution of $29 \%$. In case of horizontal application of PV panels, utilizable area can be increased to $44 \%$, delivering an electricity contribution of $36 \%$. Transferring these results in terms of energy per unit of the conditioned area gives respective values of around $13 \mathrm{kWh} / \mathrm{m}^{2} / \mathrm{yr}, 24 \mathrm{kWh} / \mathrm{m}^{2} / \mathrm{yr}, 37$ $\mathrm{kWh} / \mathrm{m}^{2} / \mathrm{yr}$ and $45 \mathrm{kWh} / \mathrm{m}^{2} / \mathrm{yr}$ for the four scenarios as indicated in Table 8 . A comparison between building energy breakdown and PV generation is illustrated graphically in Figure 11.

The shading effect as a result of PV panels can reduce the cooling load by 1.0\%, 1.8, 2.8\% and 3.2\% for UA of $0.15,0.25,0.40$ and 0.44 respectively as also indicated in Table 8. It is noteworthy that PV panels can also result into increased heating load in winter. In the climatic conditions considered in this study however the increase in heating load is almost negligible compared to the reduction in cooling load and hence the former is neglected.

Table 8: Energy Contribution to a Typical Villa by Rooftop PV

\begin{tabular}{|l|c|c|c|c|}
\hline \multirow{2}{*}{} & \multicolumn{3}{|c|}{ Tilted 24 } & Horizontal \\
\cline { 2 - 5 } & $\mathrm{UF}=0.15$ & $\mathrm{UF}=0.25$ & $\mathrm{UF}=0.40$ & $\mathrm{UF}=0.44$ \\
\hline PV energy production $(\mathrm{kWh} / \mathrm{yr})$ & 6,551 & 12,008 & 18,550 & 22,703 \\
\hline
\end{tabular}




\begin{tabular}{|l|c|c|c|c|}
\hline $\begin{array}{l}\text { PV energy production per unit of } \\
\text { conditioned area }\left(\mathrm{kWh} / \mathrm{m}^{2} / \mathrm{yr}\right)\end{array}$ & 13 & 24 & 37 & 45 \\
\hline $\begin{array}{l}\text { Share of PV generation in the total } \\
\text { building consumption (\%) }\end{array}$ & 10 & 19 & 29 & 36 \\
\hline Cooling load saving (\%) & 1.0 & 1.8 & 2.8 & 3.2 \\
\hline
\end{tabular}

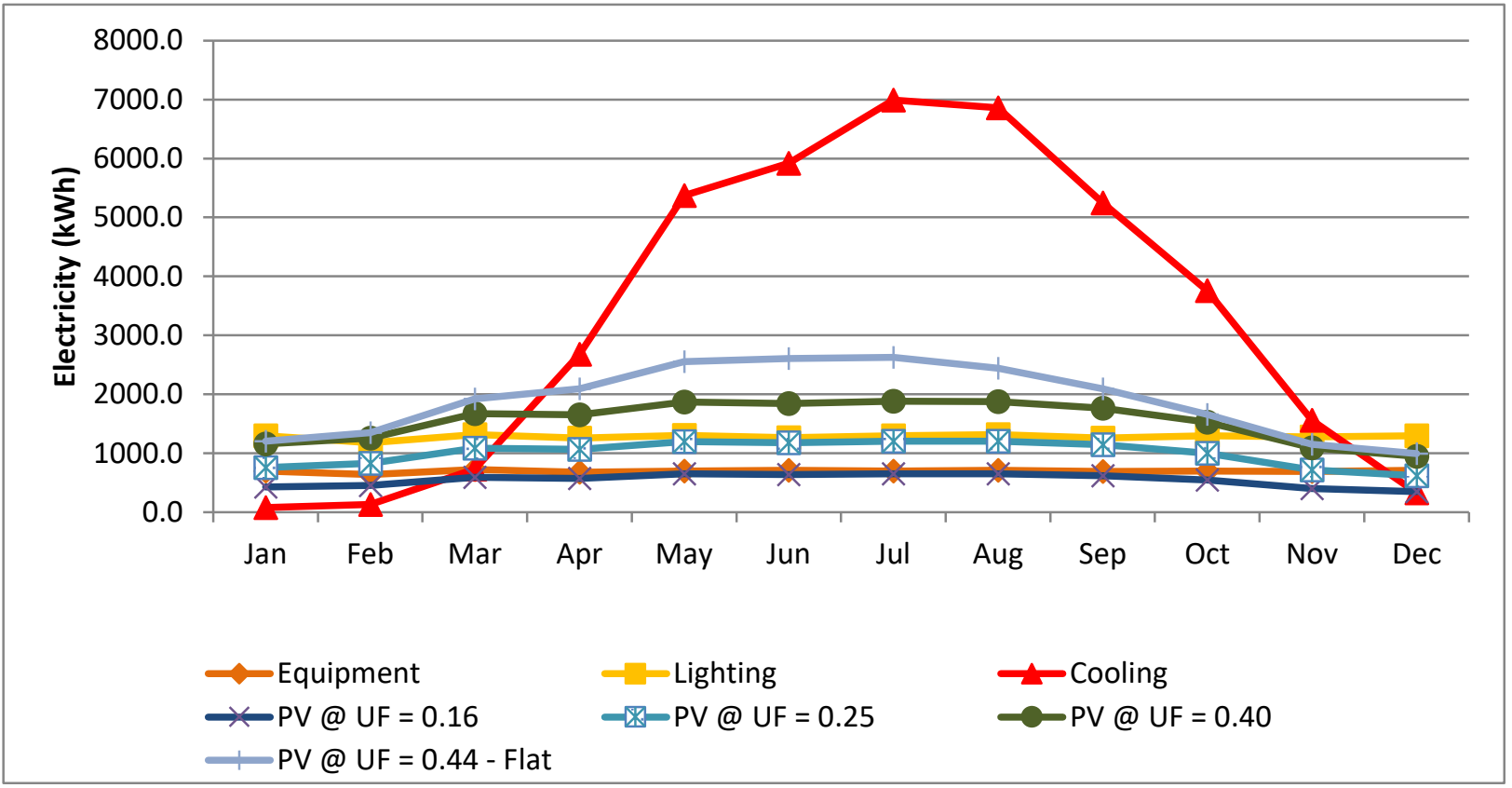

Figure 11: Total Electricity Produced by PV Panels at the City Scale

\subsection{Energy Potential at City Level}

The energy generation at the city scale has been computed by multiplying the average electricity production per unit area of PV panels $\left(\mathrm{kWh} / \mathrm{m}^{2} / \mathrm{yr}\right.$ ) with the total PVA (quantified in section 3). The average electricity production, from tilted PV, for apartments and villas is found to be $207 \mathrm{kWh} / \mathrm{m}^{2} / \mathrm{yr}$ and $213 \mathrm{kWh} / \mathrm{m}^{2} / \mathrm{yr}$ respectively, the difference being because of the variation in the architectural features of the roofs. The results indicate that the total annual energy production for the optimal tilt angle equals to $302.0 \mathrm{GWh}$ and $494.6 \mathrm{GWh}$ for apartments and villas respectively. The total annual energy production for flat installation gives figures of $296.2 \mathrm{GWh}$ and $460.9 \mathrm{GWh}$ for apartments and villas respectively. Table 9 summarizes the findings of the total electricity produced by PV panels considering the existing roof conditions. The total annual electricity produced from tilted PV panels is $5 \%$ more than that produced from flat PV panels. 
Table 9: Comparison between Building Energy Breakdown and PV Generation

\begin{tabular}{|l|c|c|c|}
\hline Type & $\begin{array}{c}\text { Total PVA Area } \\
\left(\mathbf{m}^{\mathbf{2}}\right)\end{array}$ & $\begin{array}{c}\text { Total Energy Produced - } \\
\text { Titled } \mathbf{2 4}^{\circ} \\
(\mathbf{G W h} / \mathrm{yr})\end{array}$ & $\begin{array}{c}\text { Total Energy Produced - } \\
\text { Flat } \\
(\mathbf{G W h} / \mathbf{y r})\end{array}$ \\
\hline Apartment & $1,460,340$ & 302.0 & 296.2 \\
\hline Villa & $2,323,072$ & 494.6 & 460.9 \\
\hline Total & $3,783,412$ & 796.6 & 757.1 \\
\hline
\end{tabular}

439 The LCOE of the PV system for the studied villa building is found to be SAR0.29/kWh $(\$ 0.078 / \mathrm{kWh})$.

440 Two more scenarios have been worked out considering increased tariff and financial incentive by the 441 government. It is found that with a 65\% jump in electricity tariff PV system will become an economically 442 viable solution. In terms of financial support, the analysis depicted that with $35 \%$ of the initial cost covered 443 by the government as an incentive, PV would be a viable solution. A sensitivity analysis has also been 444 conducted to further study the impact of three parameters: PV capital cost, interest rate and electricity rates. 445 Net present value (NPV), used here as an economic indicator, can be evaluated by considering the present 446 value of all outgoing (expenditures) and incoming (benefits) cash flows for the study period. The error 447 range considered for the sensitivity analysis in this study is $\pm 50 \%$. It can be concluded from Figure 12 that 448 electricity rate is the most critical factor in the economic feasibility of PV systems, followed by interest rate 449 and PV capital cost. 


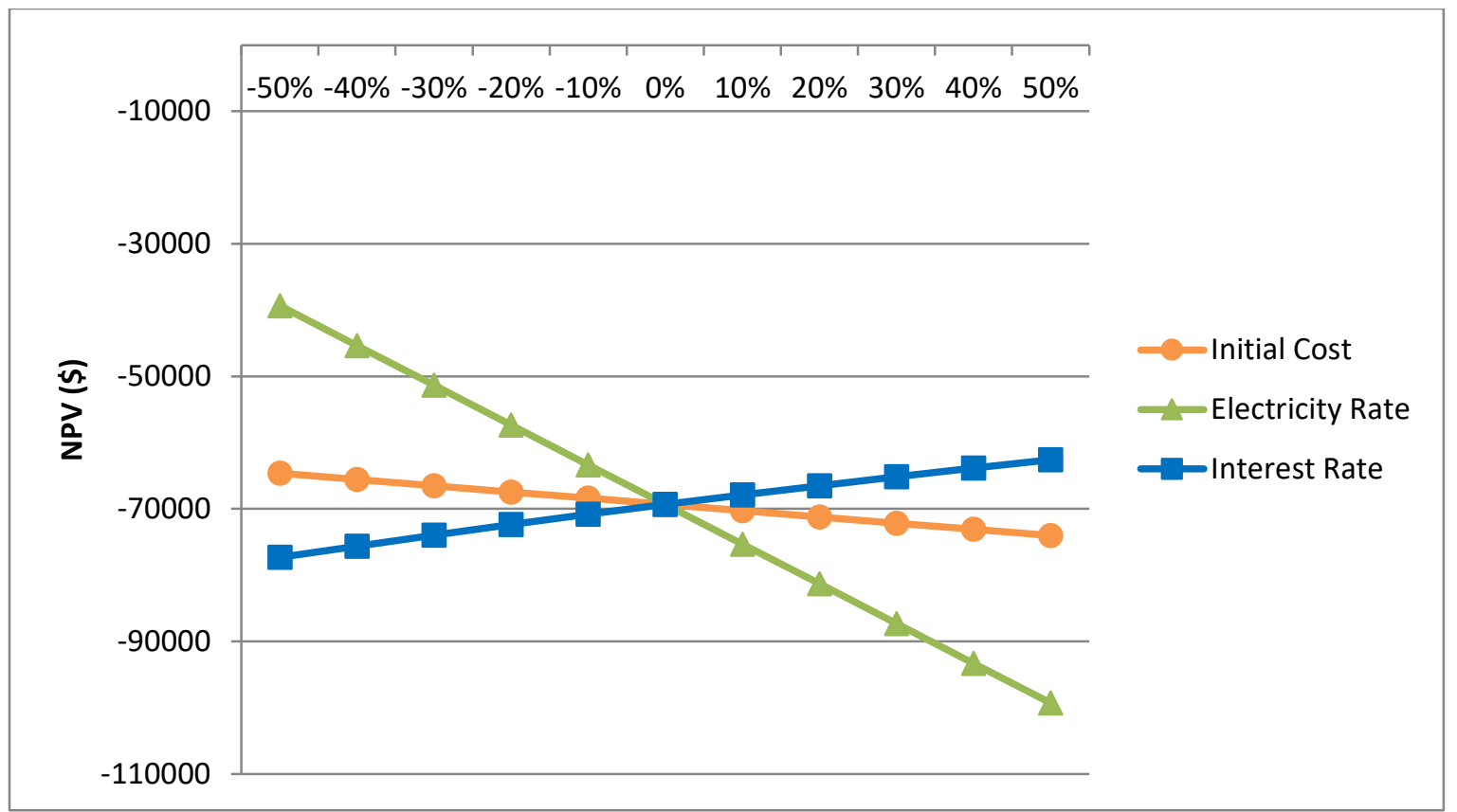

Figure 12: Sensitivity Analysis for Rooftop PV Corresponding to the Investigated Villa

\section{CONCLUSIONS}

This work investigates the overall energy contribution made by rooftop PV systems to residential buildings in hot-humid climatic conditions. The impact on the energy performance of buildings has been determined by examining both the power output from PV panels and the energy saving as result of cooling load reduction due to the shading effect of panels. The study area spans over $100 \mathrm{~km}^{2}$ in the city of Al-Khobar in Saudi Arabia covering 33,000 residential units. Restrictions posed by building rooftops towards application of PV have been studied and categorized into five types: structural (annexes, parapet walls, roof geometry), services (dish antennas, water tanks, AC units), accessibility (maintenance, inter-row spacing), shading and others (courtyard, clotheslines). An analysis based upon high resolution satellite images, GIS models and building audits reveals that on average $21 \%$ and $28 \%$ of apartment and villas rooftops can be utilized for PV applications respectively. Results of detailed modeling undertaken with the help of PVSOL ${ }^{\circledR}$ 463 reveal that PV systems have an average specific annual yield of $1,391 \mathrm{kWh} / \mathrm{kWp}$ and exhibit a performance ratio of $70 \%$. Findings of the building energy modeling suggest that the shading effect of PV panels on roofs can result into average annual irradiance reduction of $13 \%$. With its current roof utilization of $15 \%$ the case study villa building can have $10 \%$ of its annual energy requirements met by the power output from the rooftop PV system. Increasing the roof utilizable area to $40 \%, 29 \%$ of the villa's annual energy requirements can be met by the PV output, and cooling load can be reduced by $3 \%$. The total annual PV output for the studied urban scale area with existing roof conditions has been found to be $796.6 \mathrm{GWh}$ and 
471 system is not a viable option under the current tariff structure as it has LCOE equivalent to SAR0.29/kWh

$472(\$ 0.078 / \mathrm{kWh})$. Sensitivity analysis reveals that electricity tariff has the most significant impact on the 473 economic feasibility of the PV system followed by interest rate and its capital cost.

\section{REFERENCES}

475

476

477

478

479

480

481

482

483

484

485

486

487

488

489

490

491

492

493

494

495

496

497

498

Adaramola, M.S., Paul, S.S., 2017. Economic Analysis and Potential Feed-in Tariff of Grid-Connected PV Systems in Nigeria 36. doi:10.1002/ep

Al Garni, H.Z., Awasthi, A., Ramli, M.A.M., 2018. Optimal design and analysis of grid-connected photovoltaic under different tracking systems using HOMER. Energy Conversion and Management 155, 42-57. doi:10.1016/j.enconman.2017.10.090

Alkhathlan, K., Javid, M., 2015. Carbon emissions and oil consumption in Saudi Arabia. Renewable and Sustainable Energy Reviews 48, 105-111. doi:10.1016/j.rser.2015.03.072

Alrashed, F., Asif, M., 2014. Trends in residential energy consumption in Saudi Arabia with particular reference to the Eastern Province. Journal of Sustainable Development of Energy, Water and Environment Systems 2, 376-387. doi:10.13044/j.sdewes.2014.02.0030

Asif, M., 2016. Urban scale application of solar PV to improve sustainability in the building and the energy sectors of KSA. Sustainability (Switzerland) 8. doi:10.3390/su8111127

Ban-Weiss, G., Wray, C., Delp, W., Ly, P., Akbari, H., Levinson, R., 2013. Electricity production and cooling energy savings from installation of a building-integrated photovoltaic roof on an office building. Energy and Buildings 56, 210-220. doi:10.1016/j.enbuild.2012.06.032

Baras, A., Bamhair, W., Alkhoshi, Y., Alodan, M., 2012. Opportunities and challenges of solar energy in Saudi Arabia. World Renewable Energy Forum 4721.

Baras, A., Jones, R.K., Alqahtani, A., Alodan, M., Abdullah, K., 2017. Measured soiling loss and its economic impact for PV plants in central Saudi Arabia. 2016 Saudi Arabia Smart Grid Conference, SASG 2016 1-7. doi:10.1109/SASG.2016.7849657

BP Solar, n.d. 190W Photovoltaic module - BP 4190T [WWW Document]. URL http://smdelectricalservices.co.uk/ESW/Files/BP4190T_datasheet.pdf (accessed 5.29.18).

Dehwah, A.H.A., Asif, M., Rahman, M.T., 2018. Prospects of PV Application in Unregulated Building Rooftops in Developing Countries: A Perspective from Saudi Arabia. Energy and Buildings 171, 
500

501

502

503

504

505

506

507

508

509

510

511

512

513

514

515

516

517

518

519

520

521

522

523

524

525

526

Dominguez, A., Kleissl, J., Luvall, J.C., 2011. Effects of solar photovoltaic panels on roof heat transfer. Solar Energy 85, 2244-2255. doi:10.1016/j.solener.2011.06.010

Dong, C., Dong, X., Jiang, Q., Dong, K., Liu, G., 2018. What is the probability of achieving the carbon dioxide emission targets of the Paris Agreement? Evidence from the top ten emitters. Science of The Total Environment 622-623, 1294-1303. doi:10.1016/j.scitotenv.2017.12.093

Energy Information Administration (EIA), 2016. Updated Capital Cost Estimates for Utility Scale Electricity Gener ating Plants. Energy Information Administration (EIA).

Export.gov, 2017. Saudi Arabia - Energy [WWW Document]. URL https://www.export.gov/article?id=Saudi-Arabia-Energy (accessed 5.29.18).

Gautam, B.R., Li, F., Ru, G., 2015. Assessment of urban roof top solar photovoltaic potential to solve power shortage problem in Nepal. Energy and Buildings 86, 735-744. doi:10.1016/j.enbuild.2014.10.038

Hong, T., Koo, C., Park, J., Park, H.S., 2014. A GIS (geographic information system)-based optimization model for estimating the electricity generation of the rooftop PV (photovoltaic) system. Energy 65, 190-199. doi:10.1016/j.energy.2013.11.082

Hutchins, M., 2017. Saudi Arabia begins tender process for 300 MW PV plant.

Joint Research Centre (JRC), 2012. Photovoltaic Geographical Information System (PVGIS).

Kapsalis, V.C., Vardoulakis, E., Karamanis, D., 2014. Simulation of the cooling effect of the roof-added photovoltaic panels. Advances in Building Energy Research 8, 41-54.

doi:10.1080/17512549.2014.890534

Karteris, M., Slini, T., Papadopoulos, A.M., 2013. Urban solar energy potential in Greece: A statistical calculation model of suitable built roof areas for photovoltaics. Energy and Buildings 62, 459-468. doi:10.1016/j.enbuild.2013.03.033

Khan, H., Asif, M., 2017. Impact of Green Roof and Orientation on the Energy Performance of Buildings: A Case Study from Saudi Arabia. Sustainability 9, 640. doi:10.3390/su9040640

Khan, J., Arsalan, M.H., 2016. Estimation of rooftop solar photovoltaic potential using geo-spatial techniques: A perspective from planned neighborhood of Karachi - Pakistan. Renewable Energy 90, 
528

529

530

531

532

533

534

535

536

537

538

539

540

541

542

543

544

545

546

547

548

549

550

551

552

553

554

Khan, M., Asif, M., Stach, E., 2017. Rooftop PV Potential in the Residential Sector of the Kingdom of Saudi Arabia. Buildings 7, 46. doi:10.3390/buildings7020046

Ko, L., Wang, J.C., Chen, C.Y., Tsai, H.Y., 2015. Evaluation of the development potential of rooftop solar photovoltaic in Taiwan. Renewable Energy 76, 582-595. doi:10.1016/j.renene.2014.11.077

Kurdgelashvili, L., Li, J., Shih, C.H., Attia, B., 2016. Estimating technical potential for rooftop photovoltaics in California, Arizona and New Jersey. Renewable Energy 95, 286-302. doi:10.1016/j.renene.2016.03.105

Lai, C.S., Mcculloch, M.D., 2017. Levelized cost of electricity for solar photovoltaic and electrical energy storage. Applied Energy 190, 191-203. doi:10.1016/j.apenergy.2016.12.153

Mahalik, M.K., Babu, M.S., Loganathan, N., Shahbaz, M., 2017. Does financial development intensify energy consumption in Saudi Arabia? Renewable and Sustainable Energy Reviews 75, 1022-1034. doi:10.1016/j.rser.2016.11.081

Mahmoud, A., Asif, M., Hassanain, M., Babsail, M., Sanni-Anibire, M., 2017. Energy and Economic Evaluation of Green Roofs for Residential Buildings in Hot-Humid Climates. Buildings 7, 30. doi:10.3390/buildings7020030

Miranda, R.F.C., Szklo, A., Schaeffer, R., 2015. Technical-economic potential of PV systems on Brazilian rooftops. Renewable Energy 75, 694-713. doi:10.1016/j.renene.2014.10.037

Mondal, M.A.H., Hawila, D., Kennedy, S., Mezher, T., 2016. The GCC countries RE-readiness: Strengths and gaps for development of renewable energy technologies. Renewable and Sustainable Energy Reviews 54, 1114-1128. doi:10.1016/j.rser.2015.10.098

Olivier, J.G.J. (PBL), Janssens-Maenhout, G. (EC-J., Muntean, M. (EC-J., Peters, J.A.H.W. (PBL), 2016. Trends in Global CO2 Emissions: 2016 Report. PBL Netherlands Environmental Assessment Agency \& European Commission's Joint Research Centre (JRC) 86.

Ouda, O.K.M., Raza, S.A., Nizami, A.S., Rehan, M., Al-Waked, R., Korres, N.E., 2016. Waste to energy potential: A case study of Saudi Arabia. Renewable and Sustainable Energy Reviews 61, 328-340. doi:10.1016/j.rser.2016.04.005

Peng, C., Yang, J., 2016. The Effect of Photovoltaic Panels on the Rooftop Temperature in the 
EnergyPlus Simulation Environment. International Journal of Photoenergy 2016. doi:10.1155/2016/9020567

Radhi, H., 2010. Energy analysis of facade-integrated photovoltaic systems applied to UAE commercial buildings. Solar Energy 84, 2009-2021. doi:10.1016/j.solener.2010.10.002

Sadati, S.M.S., Jahani, E., Taylan, O., Baker, D.K., 2018. Sizing of Photovoltaic-Wind-Battery Hybrid System for a Mediterranean Island Community Based on Estimated and Measured Meteorological Data. Journal of Solar Energy Engineering, Transactions of the ASME 140, 1-12. doi:10.1115/1.4038466

Sun, L.L., Yang, H.X., 2010. Impacts of the shading-type building-integrated photovoltaic claddings on electricity generation and cooling load component through shaded windows. Energy and Buildings 42, 455-460. doi:10.1016/j.enbuild.2009.10.014

Trading Economics, 2018. Saudi Arabia Interest Rate [WWW Document]. URL https://tradingeconomics.com/saudi-arabia/interest-rate (accessed 7.15.18).

Wang, Y., Tian, W., Ren, J., Zhu, L., Wang, Q., 2006. Influence of a building's integrated-photovoltaics on heating and cooling loads. Applied Energy 83, 989-1003. doi:10.1016/j.apenergy.2005.10.002

Wang, Y., Wang, D., Liu, Y., 2017. Study on Comprehensive Energy-saving of Shading and Photovoltaics of Roof Added PV Module. Energy Procedia 132, 598-603. doi:10.1016/j.egypro.2017.09.672

Wong, M.S., Zhu, R., Liu, Z., Lu, L., Peng, J., Tang, Z., Lo, C.H., Chan, W.K., 2016. Estimation of Hong Kong's solar energy potential using GIS and remote sensing technologies. Renewable Energy 99, 325-335. doi:10.1016/j.renene.2016.07.003

Zell, E., Gasim, S., Wilcox, S., Katamoura, S., Stoffel, T., Shibli, H., Engel-Cox, J., Subie, M. Al, 2015. Assessment of solar radiation resources in Saudi Arabia. Solar Energy 119, 422-438. doi:10.1016/j.solener.2015.06.031

Zhang, W., Lu, L., Peng, J., 2017. Evaluation of potential benefits of solar photovoltaic shadings in Hong Kong. Energy 137, 1152-1158. doi:10.1016/j.energy.2017.04.166

Zweibel, K., 2010. Should solar photovoltaics be deployed sooner because of long operating life at low , predictable cost ? Energy Policy 38, 7519-7530. doi:10.1016/j.enpol.2010.07.040 
